\title{
EXPERIMENTAL STUDY ON MECHANICAL AND DURABILITY PROPERTIES OF HIGH PERFORMANCE CONCRETE REPLACING COARSE AGGREGATE BY FERRO SLAG AGGREGATES
}

\author{
M.Soundararajan ${ }^{1}$, Dr.K.Nirmal Kumar ${ }^{2}$ \\ Research scholar and Assistant Professor,Department of Civil Engineering,Sona College of Technology, \\ Salem. \\ soundarcivil@gmail.com \\ Professor, Department of Civil Engineering, Kongu Engineering College, Perundurai. \\ nirmalkumar@kongu.ac.in
}

\begin{abstract}
The main objective of this research is to find out alternative materials for concrete to meet the demands of coarse aggregate for the upcoming years, to provide adequate strength at minimum cost, to make the eco-friendly structures. Use of ferro slag a waste industrial by-product of iron and steel production provides great opportunity to utilize it as an alternative to normally available aggregates (coarse). In this research, ferro slag is used and M60 grade concrete of W/C ratio 0.28 was used respectively for the replacement of 0 to $100 \%$ coarse aggregate by ferro slag aggregate for find out the optimum ratio of steel slag. In this study, a mix ratio of 1: 1.2: 2.4 is used in conventional mix. Initial optimization of ferro slag aggregate for replacing the natural coarse aggregate was find with 7 and 28 days strength. Test on compressive strength and non-destructive test at 7 and 28 days were conducted. It was concluded that possible optimum replacement of slag material was found to be $40 \%$. Split Tensile Strength and Flexural Strength and durability characteristics were carried out for conventional and optimum concrete mix to study the properties of concrete with ferro slag.
\end{abstract}

\section{Keywords}

Aggregates, Blast furnace steel slag, Compressive strength, Nondestructive test, Split Tensile Strength, Flexural Strength and durability characteristics.

\section{INTRODUCTION}

Concrete is the largest production as construction materials. The increase in demand for the ingredients of concrete is met by partial replacement of materials by the waste materials which is obtained by means of various industries. The utilization of industrial waste or secondary materials has encouraged for the production of cement and concrete in construction field. New by-products and waste materials are being generated by various industries. For many years, by-products such as fly ash, silica fume and ferro slag were considered as waste materials. Concrete prepared with such materials showed improvement in workability, strength and durability compared to normal concrete and has been used in the all type of construction. Nowadays, intensive research studies have been carried out to explore all possible reuse methods.

This paper represents about the experimental investigation of the possibility of using ferro slag in various percentage as coarse aggregate substitute in cement concrete. The attempt has made to investigate the characteristic of ferro slag concrete for various parameters like compressive strength, quality of concrete and load carrying capacity. For thousands of years sand and gravel have been used in construction of roads and building. Today, demand for sand and gravel continues to increase in construction industries. Excessive in stream sand-and-gravel mining causes the degradation of sub surface and surface flow of rivers. In stream mining lowers the stream bottom, which may lead to bank erosion and the reduction of sub surface water.

\section{EXPERIMENTAL INVESTIGATION}

\subsection{Materials Used}

The following materials were used for producing high strength concrete.

\subsubsection{Water}

Water is needed for the purpose of hydration of cement and to provide workability during mixing and placing of concrete. For this study, potable water having $\mathrm{pH} 7$ and other water quality parameters conforming to IS 456-2000 standards was used for concreting as well as curing of the specimens.

\subsubsection{Cement}

Cement is a binder, a substance that sets and hardens as the cement dries and also reacts with carbon dioxide in the air, and can bind other materials together. In the present experiments ordinary Portland cement of 53 grade conforming to IS 1489 (Part-1):1991 specifications were used in the preparation of concrete mixes.

\subsubsection{Fine Aggregate}


The Fine aggregates serve the purpose of filling all the open spaces in between the coarse particles. Thus they reduce the porosity of the final mass and considerably increase its strength. Usually natural river sand is used as fine aggregate. In the preparation of concrete mix, sand conforming to grading zone II of IS 383-1970 was used.

\subsubsection{Coarse Aggregate}

Optimum size of the coarse aggregate in most situations was about $20 \mathrm{~mm}$. They generally possess all the essential qualities of a good building stone showing very high crushing strength, low absorption value and least porosity. Testing of coarse aggregate was done as per IS 383-1970 procedures. The guidelines of coarse aggregate crushing value was tested as per IS 9376-1979, and its impact value was tested as per IS 9377-1979 standards.

\subsubsection{Ferro Slag And Super-Plasticizer}

Ferro slag used in the preparation of concrete mixes was here is collected from JSW SISCOL Plant, Mecheri, Salem. Super-Plasticizer CONPLAST (430) was used to increase the workability of the concrete mix. Its specific gravity was 1.21 .

Table 1. Properties of Cement

\begin{tabular}{|c|c|c|}
\hline SI.No & Properties or Parameters & Values \\
\hline 1 & Specific gravity & 3.15 \\
\hline 2 & Standard consistency & $29 \%$ \\
\hline 3 & Fineness (by sieve analysis) & $4.60 \%$ \\
\hline 4 & Initial setting time & 30 minutes \\
\hline
\end{tabular}

Table 2. Properties of Coarse Aggregate, Fine Aggregate and Ferro Slag

\begin{tabular}{|c|c|c|c|c|}
\hline SI.No & Properties or Parameters & $\begin{array}{c}\text { Coarse } \\
\text { Aggregate }\end{array}$ & Fine Aggregate & Ferro Slag \\
\hline 1 & Specific gravity & 2.75 & 2.64 & 2.93 \\
\hline 2 & Bulk density & $1765.0 \mathrm{~kg} / \mathrm{m}^{3}$ & $1668.0 \mathrm{~kg} / \mathrm{m}^{3}$ & $1682.0 \mathrm{~kg} / \mathrm{m}^{3}$ \\
\hline 3 & Water absorption & $0.5 \%$ & $1 \%$ & - \\
\hline 4 & Fineness modulus & 6.45 & 2.76 & - \\
\hline 5 & Impact value & $13.33 \%$ & - & $14.5 \%$ \\
\hline 6 & Crushing value & $17.3 \%$ & - & $23.3 \%$ \\
\hline 7 & Abrasion value & 26.5 & - & - \\
\hline
\end{tabular}

As can be seen from Table 1, the properties of cement are within the allowable limits. From Table 2 it was observed that the properties of coarse aggregate, and ferro slag are more or less similar.

\section{CONCRETE MIX DETAILS}

Two sets of mixes were prepared for $\mathrm{M}_{60}$ grade concrete. First Mix was ordinary conventional concrete. Second mix replacing ferro slag for coarse aggregate. Two sets of 3 cubes were tested for compressive strength, one set at 7 days and another set at 28 days.

Table 3. Concrete Mix Ratio

\begin{tabular}{|c|c|c|c|c|}
\hline Cement & $\begin{array}{c}\text { Fine } \\
\text { Aggregate }\end{array}$ & $\begin{array}{c}\text { Coarse } \\
\text { Aggregate }\end{array}$ & Water & $\begin{array}{c}\text { Super } \\
\text { plasticizer }\end{array}$ \\
\hline 1 & 1.2 & 2.4 & 0.28 & $1 \%$ \\
\hline
\end{tabular}

\section{TESTING DETAILS}

\subsection{Non- Destructive Test}

\subsubsection{Rebound Hammer Test}

Rebound hammer test was conducted for all the mixes for both 7 days and 28 days for M60 grade of concrete. 3 specimens were cast for each replacement of ferro slag aggregate for coarse aggregate. The value for each trial increases the percentage of steel slag $(0,10 \%, 20 \ldots$ up to $100 \%)$. 


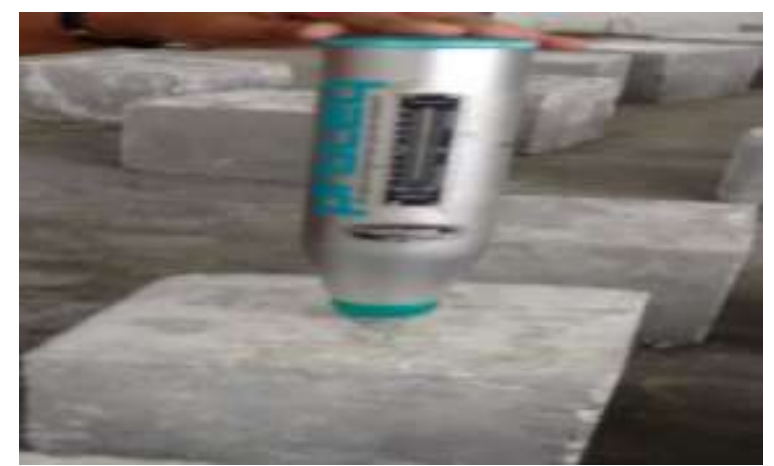

Fig 1 : Rebound Hammer Test

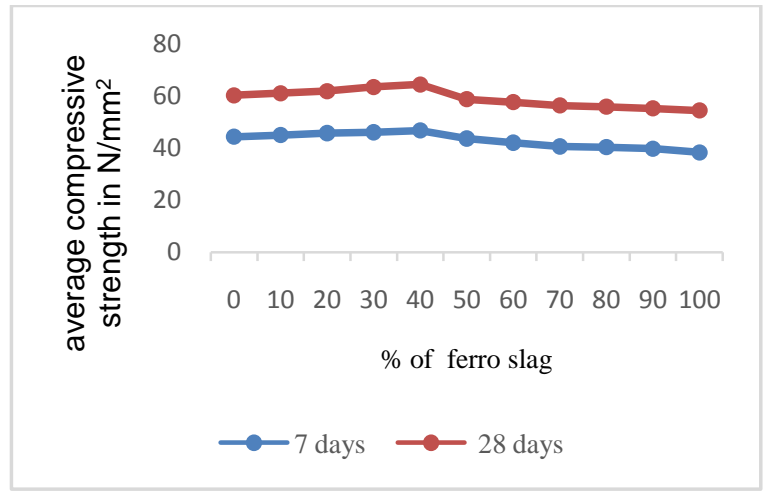

Fig 2 : Compressive Strength from Rebound Hammer

The values of average compressive strength at 7 days and 28 days, determined through rebound hammer test, are plotted against percentage of ferro slag, and are shown in Figure 2.

\subsubsection{Ultrasonic Pulse Velocity Test}

In ultrasonic pulse velocity test, three methods are there. In this paper, direct method is used. The test was conducted for all the mixes for both 7 days and 28 days for M60 grade of concrete. Three specimens were cast for each replacement of blast furnace steel slag aggregate.

From the following table 4, the quality of concrete is determined with reference to the velocity obtained.

Table 4 . Quality of concrete using UPV

\begin{tabular}{|c|c|}
\hline Pulse velocity(km/sec) & $\begin{array}{c}\text { Concrete quality } \\
\text { (Grading) }\end{array}$ \\
\hline Above 4.5 & Excellent \\
\hline 3.5 to 4.5 & Good \\
\hline 3 to 3.5 & Doubtful \\
\hline Below 3 & \\
\hline & \\
\hline
\end{tabular}

Fig 3 : Ultrasonic Pulse Velocity test 
Table 5. Ultrasonic Pulse Velocity Test Results

\begin{tabular}{|c|c|c|c|c|}
\hline \multirow{2}{*}{ Mix Id } & $\begin{array}{c}\text { \% of Coarse } \\
\text { Aggregate }\end{array}$ & \multirow{2}{*}{ \% of Ferro Slag } & \multicolumn{2}{|c|}{ Quality of Concrete } \\
\cline { 3 - 5 } & 100 & 0 & 7 Days & 28 Days \\
\hline M0 & 90 & 10 & Excellent & Excellent \\
\hline M1 & 80 & 20 & Excellent & Excellent \\
\hline M2 & 70 & 30 & Excellent & Excellent \\
\hline M3 & 60 & 40 & Excellent & Excellent \\
\hline M4 & 50 & 50 & Excellent & Excellent \\
\hline M5 & 40 & 60 & Excellent & Excellent \\
\hline M6 & 30 & 70 & Good & Good \\
\hline M7 & 20 & 80 & Good & Good \\
\hline M8 & 10 & 90 & Good & Good \\
\hline M9 & 0 & 100 & Good & Good \\
\hline M10 & & & & \\
\hline
\end{tabular}

\subsection{COMPRESSIVE STRENGTH TEST}

In this test, six cubes $\left(150 \mathrm{~mm} \times 150 \mathrm{~mm} \times 150 \mathrm{~mm}\right.$ ) were cast for each trial mix of $\mathrm{M}_{60}$ concrete.For each mix three specimens after 7 days and another set of three specimens after 28 days of curing were tested for their compressive strength, using $2000 \mathrm{kN}$ capacity compression testing machine.

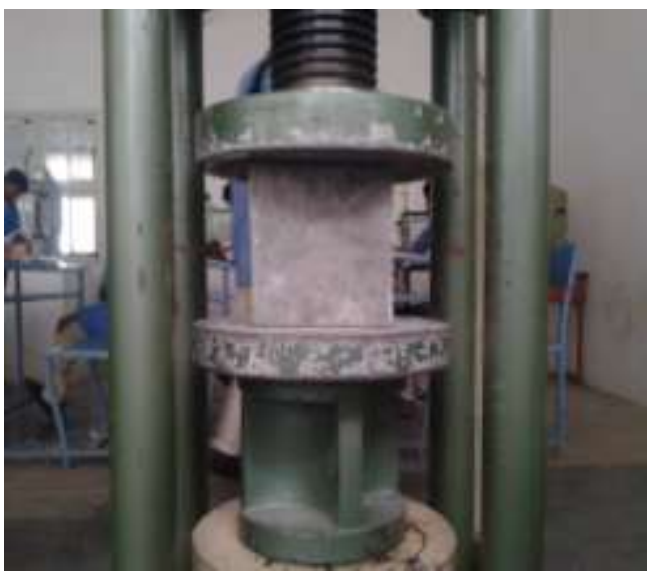

Fig 4 : Compressive Strength Test

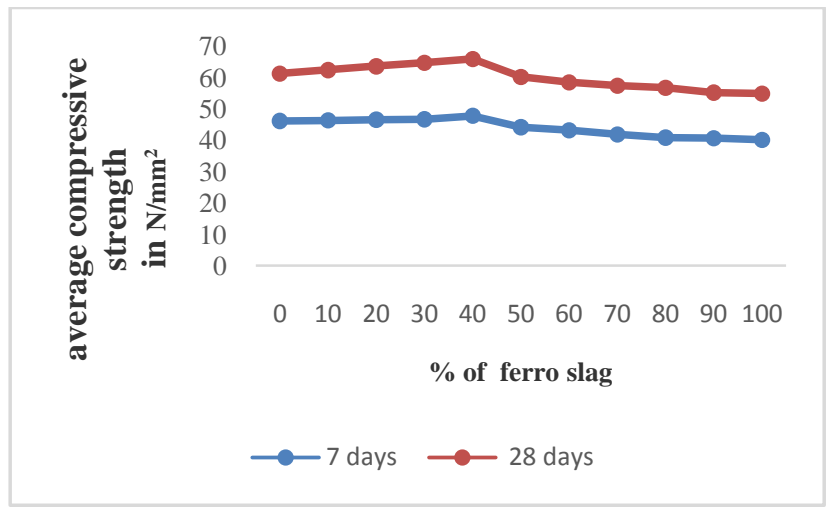

Fig 5: Compressive Strength test result from CTM

The values of Compression strength test for conventional concrete and ferro slag concrete was determined and shown in figure 5 . 


\subsection{SPLIT TENSILE STRENGTH TEST}

For tensile strength test, cylindrical specimens of dimension $100 \mathrm{~mm}$ diameter and $300 \mathrm{~mm}$ length were cast. In each mix, three cylinders were cast and tested and their average value was taken. The split tension test was conducted by using digital compression machine having $2000 \mathrm{kN}$ capacity.

Spilt Tensile strength $(\mathrm{MPa})=2 \mathrm{P} / \pi \mathrm{DL}$

Where,

$\mathrm{P}=$ Failure Load $(\mathrm{kN})$

$\mathrm{D}=$ Diameter of Specimen $(100 \mathrm{~mm})$

$\mathrm{L}=$ Length of Specimen $(300 \mathrm{~mm})$

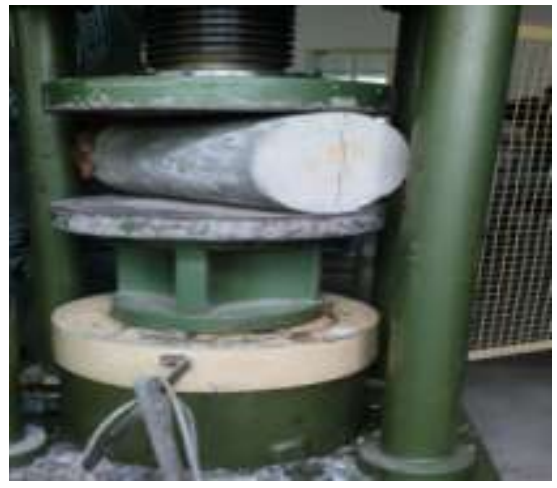

Fig 6: Split tensile Test

Table 6 .Test Results of Split Tensile Strength

\begin{tabular}{|c|c|c|}
\hline S.No & Mix ID & $\begin{array}{c}\text { Average Split } \\
\text { tensile strength in } \\
\text { (Mpa) }\end{array}$ \\
\hline 1. & S0 & 5.44 \\
\hline 2. & S40 & 6.97 \\
\hline
\end{tabular}

Test Results of splitting tensile strength for conventional and optimum percentage of ferro slag concrete of $\mathrm{M}_{60}$ grade concrete as shown in table 6

\subsection{FLEXURAL STRENGTH TEST}

For Flexural strength test, prism specimen of $100 \mathrm{~mm}$ X $100 \mathrm{~mm}$ X $500 \mathrm{~mm}$ was cast. For conventional and optimum mix, three prisms were cast and tested with two point load was applied.

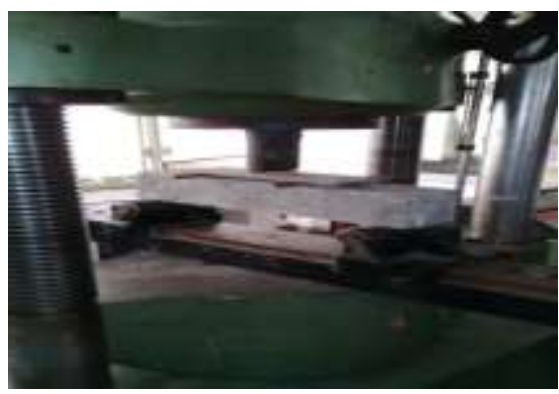

Figure 7: Flexural Strength test

A beam specimen is placed in the ultimate testing machine of $2000 \mathrm{kN}$ capacity for testing.

$\sigma=P \mid / b h^{2}$

$\mathrm{P}=$ load in Newton

$\mathrm{I}=$ length of prism in $\mathrm{mm}$ i.e. $500 \mathrm{~mm}$

$\mathrm{b}=$ breadth of prism i.e. $100 \mathrm{~mm}$

$\mathrm{h}=$ height of prism i.e. $100 \mathrm{~mm}$. 
Table 7. Test Results of Flexural Strength

\begin{tabular}{|c|c|c|}
\hline SI.NO & Mix ID & $\begin{array}{c}\text { Average flexural strength in } \\
\text { (MPa) }\end{array}$ \\
\hline 1. & S0 & 5.31 \\
\hline 2. & S40 & 6.78 \\
\hline
\end{tabular}

Table 7 shows the valves of average flexural strength of conventional concete (S0) and ferro slag aggregate concrete ( S40).

\subsection{SULPHATE ATTACK}

Sulphate attack on concrete has been reported from many others parts of the world. $100 \mathrm{~mm} \times 100 \mathrm{~mm} \times 100 \mathrm{~mm}$ size cube specimens are taken out from the curing tank after 28 days. Then $5 \%$ sodium sulphate is mixed per liter of ordinary water. Then Cubes are immersed in the sulphate solution for 60 days. After that the cubes are taken out from the sulphate solution and kept dried. Then the specimens are tested and compressive strength of the specimen was calculated.

Table 8. Loss of compressive strength of specimen subjected to sulphate Attack

\subsection{CHLORIDE ATTACK}

\begin{tabular}{|l|l|l|}
\hline mix id & $\begin{array}{l}\text { Average } \\
\text { compressive } \\
\text { strength at 28 } \\
\text { days (MPa) }\end{array}$ & $\begin{array}{l}\text { Decrease in } \\
\text { compressive } \\
\text { strength at 60 } \\
\text { days (MPa) }\end{array}$ \\
\hline S0 & 61.2 & 60.96 \\
\hline S40 & 65.8 & 65.63 \\
\hline
\end{tabular}

Chloride attack is primarily cause's corrosion of reinforcement. To test the effect of chloride on concrete, $100 \mathrm{~mm} \times 100 \mathrm{~mm}$ $x 100 \mathrm{~mm}$ size conventional and ferro slag aggregate concrete cubes were cast and kept at a room temperature. After 24 hours the specimens were cured in clean fresh water for 28 days. After curing the cubes were immersed 60 days in sodium chloride solution and tested for their compressive strength and there by durability were assessed.

Table 9. Loss of compressive strength of specimen subjected to Chloride Attack

\subsection{HYDRO CHLORIC ACID TEST}

\begin{tabular}{|c|c|c|}
\hline Mix ID & $\begin{array}{c}\text { Avg. } \\
\text { compressive } \\
\text { strength at } \\
\text { 28 days }\end{array}$ & $\begin{array}{c}\text { Decrease in } \\
\text { Compressive } \\
\text { strength (MPa) }\end{array}$ \\
\hline S0 & 61.2 & 60.7 \\
\hline S40 & 65.8 & 65.61 \\
\hline
\end{tabular}

To test the effect of hydro chloric acid on concrete, $100 \mathrm{~mm} \times 100 \mathrm{~mm} \times 100 \mathrm{~mm}$ size conventional and ferro slag aggregate concrete cubes were cast and kept at a room temperature. After 24 hours the specimens were cured in clean fresh water for 28 days. After curing the cubes were immersed in HCL Acid and tested for their decrease in compressive strength after acid attack as shown in table 4.7.

Table 10. Loss of compressive strength of specimen subjected HCL Acid Attack

\section{RESULTS \& DISCUSSION}

\begin{tabular}{|c|c|c|}
\hline Mix ID & $\begin{array}{c}\text { Avgerage } \\
\text { compressive } \\
\text { strength at } \\
\text { 28 days }\end{array}$ & $\begin{array}{c}\text { Decrease in } \\
\text { Compressive } \\
\text { strength (MPa) }\end{array}$ \\
\hline S0 & 61.2 & 60.2 \\
\hline S40 & 65.8 & 65.56 \\
\hline
\end{tabular}

From figure 2, it was noticed that the compressive strength gradually increases as the percentage of ferro slag is increased up to $40 \%$ replacement. After replacement of $40 \%$ compressive strength is gradually decreased. Hence we can 
conclude that complete replacement of coarse aggregate with ferro slag has reduced the compressive strength in concrete.

From the UPV results, shows that the quality of concrete is come under excellent while increasing the steel slag up to $60 \%$. While increasing the replacement of ferro slag above $60 \%$ quality of concrete is comes under good.

The compressive strength for M60 grade of concrete is shown in figure 2, as above. As the curing days increases the strength also increases. This compressive strength test result also similar to the rebound hammer test.

From split tensile strength test, flexure strength test and also durability test results shows, the ferro slag aggregate concrete is better than the conventional concrete.

\section{CONCLUSION}

1. In rebound hammer test, the compressive strength of the concrete was increased about 5 to $7 \%$ at 7 days curing and $7.5 \%$ is increased at 28 days curing, while replacement of $40 \%$ of ferro slag compare to the conventional concrete.

2. In ultra-sonic pulse velocity test, the quality of concrete was excellent up to $60 \%$ replacement of ferro slag aggregate.

3. The compressive strength of the concrete was increased about 3 to $8 \%$ at 7 days and28 days curing, while replacement of $40 \%$ of ferro slag compare to the conventional concrete.

4. From the result above $40 \%$ replacement of coarse aggregate with ferro slag, the compressive strength of concrete decreases linearly.

5. Split tensile test results of cylinder at 28 days have been observed. $S 40$ is $28.12 \%$ higher than the control mix.

6. Optimum ferro slag replacement shows higher flexural strength results compare to the conventional mix at 28 days. $\mathrm{S} 40$ is $27.7 \%$ higher than the control mix.

7. The durability characteristics such as resistance to sulphate attack, resistance to chloride attacks and resistance to acid attack of steel slag concrete are better than that of the controlled mix concrete

8. The chloride acid resistance of ferro slag concrete is significantly better than that of natural aggregate. ferro slag concrete is Eco-Friendly.

\section{ACKNOWLEDGEMENT}

The authors express their gratitude to the staff members and friends for their support on this study.

\section{REFERENCES}

1. Ritesh Mall, R.D.Patel, Khalid Raza, Sharda Sharma, "Comparative Strength Analysis of Concrete by Using Steel Slag as an Alternative to Normal Aggregate (Coarse) in Concrete", International Journal of Computer \& Mathematical Sciences (IJCMS), vol.3, No.5,pp.53-57,2014.

2. Dr.K.Chinnaraju,V.R.Ramkumar, K.Lineesh, S.Nithya, V.Sathish, "Study on concrete using Steel Slag As Coarse Aggregate Replacement and Ecosand As Fine Aggregate Replacement", International Journal of Research in Engineering \& Advanced Technology ,vol.1, No.3, pp.1-6,2013.

3. P.S.Kothai and R.Malathy,"Enhancement of Concrete properties by Steel Slag as a Partial Replacement Material for Coarse Aggregates", Australian Journal of Basic and Applied Sciences, Vol.7 No.12 pp.278 -285, 2013.

4. Maslehuddin.M, Alfarabi M.Sharif, Shameem.M, Ibrahim M, Barry M.S , "Comparison of properties of steel slag and crushed limestone aggregate concretes", Journal of Construction and Building Materials, Vol. 17, pp 105$112,2002$.

5. Juan M Manso, Juan A Polanco, Milagros Losanez and Javier J Gonzalez, "Durability of Concrete made with EAF Slag as Aggregates", Cement and Concrete Composite, pp 528-534,2006.

6. Dr.Pajgadel P S and Thakur N B, "Utilisation of Waste product of Steel Industry", International Journal of Engineering Research and Applications,Vol.3, 2013.

7. Papayianni I and Anastasiou E , "Production of high-strength concrete using high volume of industrial byproducts", Construction and Building Materials,Vol.24,No.8,pp.1412-1417,2010.

8. Mohammed Nadeem, Arun D. Pofale, "Experimental Investigation of Using Slag as an Alternative to Normal Aggregates (coarse and fine) in concrete", International Journal of Civil and Structural Engineering, vol. 3,pp.117$127,2012$.

9. Chawla, S.L, Gupta, R.K.(1993). In: Haddad MT, editor. Materials selection for corrosion control, Materials Park, $\mathrm{OH}$ : ASM International.

10. Feldman, R.F., Beaudoio, J.J. (1991). "Effect of cement blends on chloride and sulfate ion diffusion in concrete." II Cemento,Vol.88,pp. 3-18.

11. Irassar, E.F., Di Maio, A., Batic,O.R., (1996). "Sulfate attack on concrete with mineral admixtures." Cement and Concrete Research, Vol.26, No.1, pp.113-123, DOI: 10.1016/0008-8846(95)00195-6.

12. Mangat,P.S., Molloy,B.T.,(1991). "Influence of PFA, slag and Micro silica on Chloride-induced corrosion of reinforcement in concrete." Cement and Concrete Research, Vol.21, pp.819-834, DOI: 10.1016/0008 8846(91)90177-J.

13. Mehta, P.K. (1993). Sulfate attack on concrete: A critical review, in: R.R. Villarreal (Ed.), Concrete Durability, Universidad Autonoma de Nuevo Leon, pp. 107- 132. 
14. Muralidharan ,S., Saraswathy, V., Thangavel, K., Srinivasan, S.(2000)."Competitive role of inhibitive and aggressive ions in the corrosion of steel in concrete." Journal of AppliedElectrochemistry,Vol.30, pp.12551259,DOI: 10.1023/A:1026570120698.

15. Rasheeduzzafar, Bader, A.M., Khan M.M.(1992). " Performance of corrosion resisting steel in chloride-bearing concrete." ACI Materials Journals, Vol.89, No.5,pp.439-48, DOI: 10.14359/2379.

16. Shamsad Ahmad.(2003). "Reinforcement corrosion in concrete structures, its monitoring and service life prediction - a review." Cement and Concrete Composites, Vol. 25, No.4-5, pp. 459-471, DOI: 10.1016/s09589465(02)00086-0.

17. Tumidajski, P.J, Chan, G.W. (1996)."Effect of sulfate and carbon dioxide on chloride diffusivity." Cement and Concrete Research,Vol.26,pp.551-556, DOI: 10.1016/0008-8846(96)00019-1. 